\title{
KARAKTERISTIK BIOETANOL HASIL FERMENTASI KULIT SINGKONG
}

\author{
"Herman Yoseph Sriyana dan Ufi Nasita \\ Politeknik Katolik Mangunwijaya \\ *Email : hy_sriyana@yahoo.co.id
}

\begin{abstract}
Abstrak
Kulit singkong merupakan limbah dari singkong yang memiliki kandungan karbohidrat tinggi sehingga kulit singkong dapat dijadikan salah satu alternatif bahan baku pembuatan bioetanol. Penelitian ini bertujuan untuk mengetahui pengaruh jumlah saccharomyces cerevisiae dan waktu fermentasi terhadap yield pada pembuatan bioethanol dari kulit singkong. Proses pembuatan bioetanol ini melalui tahap - tahap yaitu pembuatan tepung kulit singkong, proses hidrolisis tepung kulit singkong kemudian menganalisa kadar glukosa, proses fermentasi dan proses distilasi. Pembuatan bioetanol dari tepung kulit singkong diawali dengan proses hidrolisis asam. Proses hidrolisis ini bertujuan untuk mengubah polisakarida (pati) menjadi monosakarida (glukosa). Asam yang digunakan adalah asam klorida ( $\mathrm{HCl}$ ) 0,1 $N$, tepung kulit singkong dalam larutan asam dihidrolisa pada suhu $92^{\circ} \mathrm{C}$ selama 1 jam. Dari hasil percobaan hidrolisis tepung kulit singkong kemudian dilakukan analisa kadar glukosa. Pada proses fermentasi, buburan hasil hidrolisa asam yang akan difermentasi sebanyak 150 gram. Glukosa akan diuraikan menjadi etanol oleh ragi Saccharomyces cerevisiae. Dalam penelitian ini dilakukan variasi penambahan fermipan (3 gram dan 5 gram) dan waktu fermentasi (2 hari, 4 hari, 6 hari dan 10 hari), jumlah urea 3 gram. Proses distilasi untuk memisahkan etanol dilakukan selama 1 jam atau sampai tidak terjadi tetesan lagi, pada suhu $78^{\circ} \mathrm{C}-80^{\circ} \mathrm{C}$. Pada penelitian ini didapatkan yield maksimum pada waktu fermentasi 6 hari dengan jumlah fermipan 5 gram yaitu 3,7 ml bioetanol.
\end{abstract}

Kata kunci : kulit singkong, bioethanol, hidrolisa, fermentasi.

\section{PENDAHULUAN}

Penggunaan bahan bakar fosil selain mencemari lingkungan juga memiliki ketersediaan yang terbatas, sehingga menyebabkan krisis energi dunia. Krisis energi dunia merupakan masalah yang sedang dihadapi banyak negara termasuk Indonesia. Krisis ini terjadi akibat ketergantungan pemenuhan energi bahan bakar yang digunakan berasal dari bahan bakar fosil. Masalah ini dapat diatasi dengan upaya pemanfaatan sumber energi alternatif untuk dijadikan sebagai bahan bakar (Haryono dkk., 2010). Energi bahan bakar alternatif salah satunya adalah bioetanol yang dapat diproduksi dari bahan yang mengandung karbohidrat dengan cara fermentasi glukosa dengan menggunakan ragi (saccharomyces cerevisiae) (Sriwulan, 2012).

Kulit singkong merupakan bagian kulit luar umbi singkong, tidak digunakan pada waktu penggunaan umbi singkong, hanya dijadikan untuk bahan pakan ternak. Tanaman singkong di Indonesia banyak diproduksi dan kulit singkong tersedia dalam jumlah yang sangat banyak dan belum dimanfaatkan dengan baik. Persentase jumlah limbah kulit bagian luar sebesar $0,5-2 \%$ dari berat total singkong segar dan limbah kulit bagian dalam sebesar 8 -
$15 \%$. Kulit singkong mengandung karbohidrat cukup tinggi. Hasil analisa awal kulit singkong yaitu mengandung $36,5 \%$ pati atau amilum (Artiyani dan Soedjono, 2011). Kandungan pati kulit ubi kayu yang cukup tinggi, memungkinkan digunakan sebagai sumber energi bagi mikroorganisme. (Nurhayani, dkk., 2000)

Etanol merupakan produk hasil fermentasi yang berasal dari sumber hayati. Bahan baku pembuatan etanol dapat berasal dari bahan yang mengandung selulosa, polisakarida, dan monosakarida. Bioetanol dapat diartikan sebagai bahan kimia yang diproduksi dari bahan pangan yang mangandung pati, seperti ubi kayu, ubi jalar, jagung, tebu dan sagu. Semuanya merupakan tanaman penghasil karbohidrat yang sangat mudah ditemukan di Indonesia karena iklim dan keadaan tanah Indonesia yang mendukung pertumbuhan tanaman tersebut.

Hidrolisis adalah suatu proses antara reaktan dengan air agar suatu senyawa pecah terurai. Reaksi Hidrolisis:

$(\mathrm{C} 6 \mathrm{H} 10 \mathrm{O} 5) \mathrm{n}+\mathrm{n} \mathrm{H} 2 \mathrm{O} \longrightarrow \mathrm{n} \mathrm{C6H12O6}$

Polisakarida Air Glukosa

Reaksi antara air dan pati berlangsung sangat lambat sehingga diperlukan bantuan 
katalisator untuk memperbesar kereaktifan air. Katalisator bisa berupa asam maupun enzim. Katalisator asam yang biasa digunakan adalah asam klorida, asam nitrat dan asam sulfat. Salah satu proses hidrolisis yaitu hidrolisis asam, dimana katalisatornya menggunakan asam. Di dalam industri asam yang dipakai adalah $\mathrm{H} 2 \mathrm{SO} 4$ dan $\mathrm{HCl}$. $\mathrm{HCl}$ lebih menguntungkan karena lebih reaktif dibandingkan $\mathrm{H} 2 \mathrm{SO} 4$. (Groggins,1992)

Faktor-faktor yang berpengaruh pada hidrolisis pati antara lain :

1. Suhu

Dari kinetika reaksi, semakin tinggi suhu reaksi makin cepat pula jalannya reaksi. Tetapi apabila proses berlangsung pada suhu yang tinggi, konversi akan menurun. Hal ini disebabkan adanya glukosa yang pecah menjadi arang.

2. Waktu

Semakin lama waktu hidrolisis, konversi yang dicapai semakin besar dan pada batas waktu tertentu akan diperoleh konversi yang relatif baik dan apabila waktu tersebut diperpanjang, pertambahan konversi kecil sekali.

3. Pencampuran pereaksi

Karena pati tidak larut dalam air maka pengadukan perlu diadakan agar persentuhan butir-butir pati dan air dapat berlangsung dengan baik.

4. Konsentrasi katalisator

Penambahan katalisator bertujuan memperbesar kecepatan reaksi. Jadi semakin banyak jumlah katalisator yang dipakai makin cepat reaksi hidrolisis. Dalam waktu tertentu pati yang berubah menjadi glukosa juga meningkat.

5. Kadar suspensi pati

Perbandingan antara air dan pati yang tepat akan membuat reaksi hidrolisis berjalan cepat.

(Groggins,1992)

Fermentasi adalah suatu proses perubahan kimia dalam suatu substrat organik yang dapat berlangsung karena aksi katalisator biokimia, yaitu enzim yang dihasilkan oleh mikrobia tertentu. (Tjokroadikoesoemo, 1986)

Fermentasi gula oleh ragi, misalnya Saccharomyces cerevisiae dapat menghasilkan etil alkohol (etanol) dan $\mathrm{CO} 2$ melalui reaksi sebagai berikut:

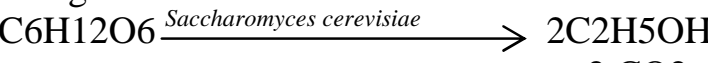

Glukosa etanol

Mikroba yang digunakan pada proses fermentasi yaitu ragi Saccharomyces cerevisiae karena mikroba Saccharomyces cerevisiae memiliki beberapa kelebihan dibandingkan mikroba lain, Saccharomyces cerevisiae dapat menghasilkan alkohol hingga 2\% dalam 72 jam (O'Leary dkk., 2004). Mikroba Saccharomyces cerevisiae menghasilkan enzim invertase dan enzim zimase dengan adanya kedua enzim tersebut mikroba Saccharomyces cerevisiae dapat mengkorversi gula menjadi etanol. Gula dari kelompok disakarida akan dihidrolisis enzim invertase menjadi monosakarida selanjutnya enzim zimase akan mengkonversi monosakarida menjadi alcohol dan karbondioksida (O'Leary dkk., 2004).

Reaksi ini merupakan dasar dari pembuatan tape, brem, tuak, anggur minuman, bir, roti dan lain - lain. (Winarno, 1984)

Faktor-faktor yang mempengaruhi proses fermentasi:

a) Keasaman $(\mathrm{pH})$

Tingkat keasaman sangat berpengaruh dalam perkembangan bakteri. Kondisi keasaman yang baik untuk pertumbuhan bakteri adalah 4 - 5 (Winarno, 1984 ).

b) Mikroba

Fermentasi biasanya dilakukan dengan menggunakan kultur murni yang dihasilkan di laboratorium. Kultur ini dapat disimpan dalam keadaan kering atau dibekukan. Berbagai macam jasad renik dapat digunakan untuk proses fermentasi antara lain yeast. Yeast tersebut dapat berbentuk bahan murni pada media agaragar atau dalam bentuk dry yeast yang diawetkan.

( Winarno, 1984 )

c) Suhu

Suhu fermentasi sangat menentukan macam mikroba yang dominan selama fermentasi. Tiap-tiap mikroorganisme memiliki suhu pertumbuhan optimal, yaitu suhu yang memberikan pertumbuhan terbaik dan perbanyakan diri secara tercepat. Pada suhu $30^{\circ} \mathrm{C}$ mempunyai keuntungan terbentuk alkohol lebih banyak karena ragi bekerja optimal pada suhu itu. ( Winarno, 1984 )

d) Oksigen

Udara atau oksigen selama proses fermentasi harus diatur sebaik mungkin untuk memperbanyak atau menghambat mikroba tertentu. Setiap mikroba 
membutuhkan oksigen yang berbeda jumlahnya untuk pertumbuhan atau membentuk sel - sel baru dan untuk fermentasi.

Misalnya ragi roti (Saccharomyces cerevisiae) akan tumbuh lebih baik pada keadaan aerobik, tetapi akan melakukan fermentasi terhadap gula jauh lebih cepat pada keadaan anaerobik.

( Winarno, 1984 )

e) Makanan

Semua mikroorganisme memerlukan nutrient yang akan menyediakan:

1) Energi biasanya diperoleh dari subtansi yang mengandung karbon.

2) Nitrogen untuk sintesis protein. Salah satu contoh sumber nitrogen yang dapat digunakan adalah urea.

3) Mineral yang dipergunakan mikroorganisme salah satunya adalah asam phospat yang dapat diambil dari pupuk NPK.

4) Vitamin, sebagian besar sumber karbon dan nitrogen alami sudah mengandung semua atau beberapa vitamin yang dibutuhkan mikroorganisme. ( Gaman, 1992)

Makalah ini bertujuan untuk mengkaji pengaruh jumlah Saccharomyces Cerevisiae (ragi) yang ditambahkan dan waktu fermentasi terhadap volume etanol yang dihasilkan.

\section{METODOLOGI}

Penelitian ini menggunakan metode Rancangan Acak Lengkap Faktorial (RALF) dengan 2 variabel bebas, setiap variabel bebas masing-masing 2 dan 3 perlakuan yang dilakukan secara eksperimental di laboratorium Akademi Kimia Industri Santo Paulus Semarang.

\section{Variabel Penelitian}

1) Variable bebas : Jumlah yeast/ ragi yang ditambah (3 gram, dan 5 gram) dan waktu fermentasi (2 hari, 4 hari ,6 hari dan 10 hari).

2) Variable tetap : Suhu fermentasi (27$30^{\circ} \mathrm{C} /$ suhu kamar), massa larutan hasil hidrolisa yang akan difermentasi (150 g)

3) Variabel terikat : volume etanol

\section{Alat dan Bahan}

Alat dan bahan yang digunakan dalam penelitian yaitu neraca analitik, kassa asbes, tripot, botol plastik, thermometer alkohol, pengaduk, pendingin leibig, gelas arloji, erlenmeyer, pipet volume, gelas ukur, bunsen, pipet tetes, kertas saring, beakerglass, corong kaca, pipet serum, labu takar, rangkaian alat fermentasi, rangkaian alat distilasi, pisau, kulit singkong, asam klorida $(\mathrm{HCl})$, natrium hidroksida $(\mathrm{NaOH})$, aquadest, kertas $\mathrm{pH}$, yeast/ragi roti (Merek fermipan), urea.

\section{Prosedur Penelitian}

Beberapa tahap yang dilakukan dalam penelitian ini adalah :

\section{Tahap pendahuluan (Pembuatan Tepung Kulit Singkong)}

Membersihkan kulit singkong segar dari kulit tipisnya lalu mencucinya dengan air bersih, kemudian dipotong menjadi bagianbagian yang lebih kecil. Mengeringkan kulit singkong dengan sinar matahari, kemudian menghaluskan kulit singkong menggunakan blender dan diayak untuk dijadikan tepung.

\section{Tahap Hidrolisis Asam dengan HCl}

Menimbang tepung kulit singkong $240 \mathrm{~g}$. Memasang rangkaian alat hidrolisis. Memasukkan larutan Asam Klorida 0,1 N sebanyak $1840 \mathrm{ml}$ kedalam beaker glass dan memanaskan hingga mendidih. Memasukkan tepung kulit singkong tersebut ke dalam beaker glass dan mengaduknya menggunakan pengaduk merkuri selama 1 jam. Hidrolisa bisa dilakukan beberapa kali sesuai kapasitas. Membiarkan hasil hidrolisis dingin sampai suhu kamar. Menganalisa kadar glukosa hasil proses hidrolisis.

\section{Tahap Fermentasi}

Mengambil buburan hasil hidrolisis sebanyak 150 gram dan mengatur $\mathrm{pH}=4,5$ dengan menambahkan $\mathrm{NaOH}$. Kemudian ditambah dengan 3 gram urea yang telah dilarutkan dalam aquadest. Setelah itu, ditambahkan dengan ragi (Sacharomyces cereviceae) sesuai variable. Botol wadah untuk fermentasi disterilkan terlebih dahulu. Masukkan buburan lalu ditutup rapat kemudian didiamkan dengan waktu sesuai variabel.

\section{Destilasi}

Proses pemisahan dilakukan dengan cara destilasi. Pada proses ini dilakukan pemanasan pada suhu $78^{\circ} \mathrm{C}-80^{\circ} \mathrm{C}$ selama 1 jam atau sampai tidak menetes lagi. 


\section{Prosedur Analisa}

\section{Analisa Kadar Glukosa}

- Membuat larutan soxhlet : membuat larutan 1 yaitu melarutkan sebanyak 3,47 gram $\mathrm{CuSO} 4.5 \mathrm{H} 2 \mathrm{O}$ dalam aquadest sampai $50 \mathrm{cc}$ (menggunakan labu takar), membuat larutan 2 yaitu melarutkan sebanyak 17,3 gram $\mathrm{KNa}$ tatrat dan 5 gram $\mathrm{NaOH}$ (dilarutan dengan sebagian aquadest) dalam aquadest sampai 50 cc (menggunakan labu takar), mencampur larutan 1 dan 2 masing masing $10 \mathrm{cc}$.

- Melarutkan 100 gram sampel dalam aquadest $100 \mathrm{cc}$, mengaduk dan menyaring larutan tersebut, masukkan dalam labu takar $100 \mathrm{cc}$.

- Memanaskan $1 / 2 \mathrm{cc}$ reagen soxhlet ditambah $10 \mathrm{cc}$ aquadest sampai mendidih, kemudian menambahkan $1 \mathrm{cc}$ indikator methylene blue, titrasi sampai TAT (warna biru hilang) ulangi 3 kali

\section{HASIL DAN PEMBAHASAN}

Pada penelitian yang dilakukan untuk mengetahui pengaruh jumlah saccharomyces cerevisiae dan waktu fermentasi pada pembuatan bioetanol dari kulit singkong dengan metode fermentasi dengan parameter volume etanol yang dihasikan, didapatkan data hasil penelitian pada Tabel 1 .

Table 1 Volume Etanol yang Dihasilkan

\begin{tabular}{|c|c|c|c|c|}
\hline \multirow[b]{2}{*}{$\begin{array}{l}\mathbf{N} \\
\mathbf{0}\end{array}$} & \multicolumn{2}{|c|}{ Variabel bebas } & \multirow{2}{*}{$\begin{array}{l}\text { Varia- } \\
\text { bel } \\
\text { tetap }\end{array}$} & \multirow{2}{*}{$\begin{array}{c}\begin{array}{c}\text { Variabel } \\
\text { terikat }\end{array} \\
\begin{array}{c}\text { Volume } \\
\text { etanol } \\
(\mathrm{ml})\end{array}\end{array}$} \\
\hline & $\begin{array}{l}\text { Jumlah } \\
\text { ragi } \\
\text { (gram) } \\
\end{array}$ & $\begin{array}{c}\text { Waktu } \\
\text { fermentasi } \\
\text { (hari) }\end{array}$ & & \\
\hline & 3 & \multirow{2}{*}{2} & & 0,51 \\
\hline & 5 & & & 0,75 \\
\hline & 3 & \multirow{2}{*}{4} & & 1,32 \\
\hline & 5 & & Suhu & 1,51 \\
\hline & 3 & \multirow{3}{*}{6} & Massa & 2,54 \\
\hline & 5 & & & 3,76 \\
\hline & 3 & & & 1.60 \\
\hline & 5 & 10 & & 1,55 \\
\hline
\end{tabular}

Dari hasil penelitian pada Tabel 1. terlihat bahwa terjadi peningkatan etanol dari hari ke 2 sampai hari ke 6. Hal ini menunjukkan bahawa semakin lama waktu fermentasi semakin banyak etanol yang dihasilkan.karena perkembangbiakan mikroba yang semakin cepat. Hari ke 10 terjadi penurunan jumlah etanol yang dihasilkan karena terjadi fermentasi lanjutan dari etanol menjadi senyawa lain seperti asam karboksilat dan ester. Kandungan glukosa yang ada pada buburan hasil hidrolisa tepung kulit singkong sangat sedikit yaitu sebesar $2,81 \%$. Prosentase tersebut diperoleh dari analisa kadar glukosa (Lane Eynon) yang dilakukan terhadap sampel buburan hasil hidrolisa tepung kulit singkong. O'Leary dkk( 2004), menyebutkan bahwa konsentrasi yang digunakan untuk fermentasi berkisar antara 14$18 \%$. Higgins (1984) menyatakan bahwa gula yang paling baik untuk proses fermentasi adalah 16-25\% dimana akan dihasilkan etanol sebesar 6-12\%. Konsentrasi gula diatas $25 \%$ akan memperlambat fermentasi, sedangkan diatas $70 \%$ proses fermentasi terhenti. Hal ini disebabkan adanya tekanan osmotik.

Grafik pengaruh jumlah saccharomyces cerevisiae (fermipan) dan waktu fermentasi terhadap volume etanol yang dihasilkan tersaji pada Gambar 1.

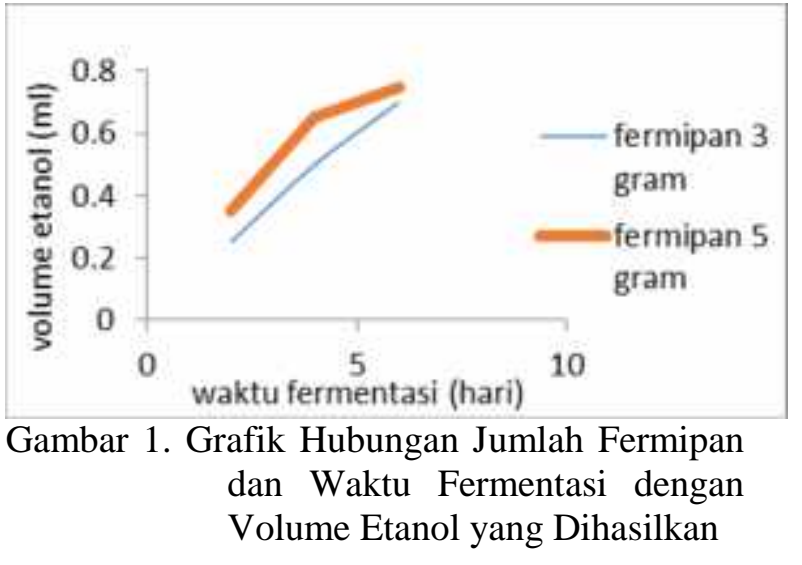

Dari grafik tersebut hasil percobaan menunjukkan semakin lama waktu fermentasi dan semakin banyak jumlah fermipan yang ditambahkan maka volume etanol yang dihasilkan semakin banyak. Pada gambar grafik tersebut, tampak waktu fermentasi yang dilakukan untuk menghasilkan volume etanol paling banyak yaitu pada hari ke-6, karena semakin lama waktu, makin banyak glukosa yang dikonversikan menjadi etanol. Sedangkan jumlah fermipan yang ditambahkan untuk menghasilkan volume etanol paling banyak yaitu 5 gram, karena semakin banyak saccharomyces cerevisiae yang akan mengkonversi glukosa menjadi etanol, sehingga etanol yang dihasilkan lebih banyak. Akan tetapi dari percobaan penelitian ini belum didapatkan kondisi (perlakuan) optimum karena 
dilihat dari grafik yang menunjukkan hubungan antara perlakuan (jumlah fermipan dan waktu fermentasi) dengan variable terikat (volume etanol) berbentuk linier.

\section{KESIMPULAN}

Pada penelitian pembuatan bioethanol dari kulit singkong ini menunjukkan semakin lama waktu fermentasi dan semakin banyak jumlah fermipan yang ditambahkan maka volume etanol yang dihasilkan semakin banyak. Etanol yang dihasilkan paling banyak pada waktu fermentasi 6 hari dengan jumlah fermipan 5 gram yaitu sebanyak $3,76 \mathrm{cc}$.

\section{DAFTAR PUSTAKA}

Artiyani, A., \& Soedjono, E. S. (2011). Bioetanol dari singkong melalui proses hidrolisis dan fermentasi dengan saccharonyces cerevisiae. Prosiding Seminar Nasional Manajemen Teknologi XIII. Surabaya: FTSP Institut Teknologi Sepuluh Nopember.

Gaman, P.M., 1992, “ ILMU PANGAN Pengantar Ilmu Pangan, Nutrisi dan Mikrobilogi ”, Gadjah Mada University Press, Yogyakarta.

Groggins, P.H., 1992, “Unit Process In Organic Synthesis", Mc Graw Hill Book Company, New York.

Haryono, R. Kurniawan, Nurhayani, A. \& Soviyani, D. A. 2010. Pembuatan Bioetanol dari Bahan Berbasis Selulosa. Jurnal Intitut Teknologi Nasional, 2(4), $1-7$.

Nurhayani, dkk., 2000, "Peningkatan Kandungan Protein Kulit Umbi Ubi Kayu melalui Proses Fermentasi", Fakultas MIPA, Universitas Haluoleo, Kendari

O'Leary, V. S., Green, R., Sullivan, B. C., \& Holsinger, V. H. (2004). Alcohol production by selected yeast strains in lactase hydrolyzed acid whey. Jurnal Biotecnology and Bioengineering, 19(7), 1019-1035.

Sriwulan, D. (2012). Pembuatan Bioetanol dari Biji Durian sebagai Energi Alternatif. Jurnal Akrad.Kim 5(3),121-126.

Tjokroadikoesoemo, S., 1986, “ HFS dan Industri Ubi Kayu Lainnya", PT Gramedia Pustaka Utama, Jakarta.

Winarno, F.G., 1984, “ Pengantar Teknologi Pangan”, PT Gramedia, Jakarta. 